(C) The Author(s), 2021. Published by Cambridge University Press. This is an Open Access article, distributed under the terms of the Creative Commons Attribution licence (http://creativecommons.org/ licenses/by/4.0/), which permits unrestricted re-use, distribution, and reproduction in any medium, provided the original work is properly cited.

\title{
THE ARTEMIS ACCORDS: EVOLUTION OR REVOLUTION IN INTERNATIONAL SPACE LAW?
}

\author{
Rossana Deplano*
}

\begin{abstract}
Adopted in October 2020, the Artemis Accords are a set of 13 provisions establishing a principled framework for the sustainable human exploration of the Moon and the other celestial bodies, including the exploitation of their natural resources. This article examines the extent to which the Artemis Accords comply with international law and international standards. It argues that, while rooted on the provisions of the Outer Space Treaty, the Artemis Accords introduce a significant innovation in international space law by replacing the anticipatory approach to the regulation of outer space activities with the staged principle of adaptive governance.
\end{abstract}

Keywords: public international law, Artemis Accords, Outer Space Treaty, Moon Agreement, exploitation of natural resources, adaptive governance, international law-making, international space law, equitable sharing of benefits.

\section{INTRODUCTION}

On 13 October 2020, eight States - namely, Australia, Canada, Italy, Japan, Luxembourg, the United Arab Emirates, the United Kingdom and the United States-signed the Artemis Accords, which are a set of 13 provisions aimed at facilitating international collaboration on sustainable human exploration projects. Ukraine joined a month later while negotiations with Brazil and other potential partners are currently under way. The Artemis Accords are part of the wider Artemis Program led by the US National Aeronautics and Space Administration (NASA). ${ }^{1}$ The main purpose of the Artemis Program is to bring the first woman and the next man to the Moon by 2024, thus paving the way for future human exploration of Mars and other celestial bodies in the solar system.

A distinctive trait of the Artemis Program is that it envisages the construction of a permanent outpost on the Moon, which includes a dedicated orbital station (the lunar 'Gateway') and a self-sustaining lunar base (the 'Moon Base Camp'). The realisation of the project requires significant economic investment, the use

* Lecturer in Law at the University of Leicester and Co-Director of the Centre for European Law and Internationalisation (University of Leicester), rd279@1eicester.ac.uk.

${ }^{1}$ NASA, Artemis Plan - NASA's Lunar Exploration Program Overview (September 2020). 
of cutting-edge technology and the utilisation of the natural resources of the Moon to build and maintain the human settlement on the lunar surface.

In order to implement the Artemis Program, NASA is seeking the international collaboration of States and commercial partners. To that end, it has elaborated a set of guidelines that will form an integral part of any subsequent agreement with international partners. In practice, States wishing to enter into collaboration with NASA must commit in advance to abide by the principles set forth in the Artemis Accords. ${ }^{2}$

The adoption of the Artemis Accords has generated mixed reactions. Among the spacefaring States, Russia has lamented the impossibility of signing the Artemis Accords due to their being perceived as protecting the interests of the United States in pursuing the exploitation of the Moon's natural resources. ${ }^{3}$ China has mostly remained silent due to NASA's legal inability to cooperate with Chinese agencies while disapproving of the US unilateral approach to regulating space activities. ${ }^{4}$ Similarly, Germany has not expressed any official position about the Artemis Accords. However, being involved in the construction of the Orion capsule (the selected spacecraft for lunar missions), Germany stands out as a vital partner in NASA's Artemis Program. ${ }^{5}$ Other international actors, such as the European Space Agency, have finalised agreements with NASA to collaborate on the creation of the lunar Gateway space station by providing two modules thereof. ${ }^{6}$

In addition, some scholars argue that the implementation of the Artemis Accords may undermine international law. For instance, Hobe warns that ' $[\mathrm{t}]$ he Artemis Accords are an attempt by the Americans to walk softly to legitimise their deviation from the Outer Space Treaty'. ${ }^{7}$ While describing the Artemis Accords as a political project, von der Dunk argues that the intention of the United States is to gather consensus around its interpretation of the Outer Space Treaty with regard to the exploitation of the Moon's resources. ${ }^{8}$

2 Artemis Accords: Principles for Cooperation in the Civil Exploration and Use of The Moon, Mars, Comets, and Asteroids for Peaceful Purposes (13 October 2020) Section 1 (describing the Artemis Accords as 'a political commitment').

3 Dmitry Rogozin, Director General of Roscosmos - the Russian Space Agency, argues that a key part of the Artemis Accords is 'too US-centric'. Statement made at the International Astronautical Congress 2020 (quoted in A Stirn, 'Do NASA's Lunar Exploration Rules Violate Space Law?' (Scientific American, 12 November 2020) <https://www.scientificamerican.com/ article/do-nasas-lunar-exploration-rules-violate-space-law/>).

4 For an overview of positions, see E Ji, MB Cerny and RJ Piliero, 'What Does China Think About NASA's Artemis Accords?' (The Diplomat, 17 September 2020) < https://thediplomat.com/ 2020/09/what-does-china-think-about-nasas-artemis-accords/>.

5 NASA Press release 18-095 (6 November 2018).

6 NASA Press release 20-107 (27 October 2020).

7 Keynote Speech, International Astronautical Congress 2020, quoted in Stirn (n 3). Treaty on Principles Governing the Activities of States in the Exploration and Use of Outer Space, Including the Moon and Other Celestial Bodies (adopted 27 January 1967, entered into force 10 October 1967) 610 UNTS 205 (Outer Space Treaty).

8 Statement made at the International Astronautical Congress 2020, quoted in Stirn (n 3). 
Taken together, the considerations above beg the question: are the Artemis Accords revolutionary? Can they significantly affect the development of international space law? This article examines the normative implications of the adoption of the Artemis Accords from two different, but interrelated, perspectives. Section II analyses the content and scope of the Artemis Accords with a view to determining the extent to which they comply with existent international law and international standards by incorporating, clarifying or integrating relevant international space law instruments. Subsequently, Section III evaluates whether the Artemis Accords significantly affect or challenge established practices in the multilateral process of law-making for outer space. Section IV concludes by arguing that, while remaining solidly grounded on the provisions of the Outer Space Treaty, the Artemis Accords introduce a significant innovation in international space law by replacing the anticipatory approach to the regulation of outer space activities with the staged ('building blocks') principle of adaptive governance.

\section{NORMATIVE CHARACTER OF THE ARTEMIS ACCORDS}

In terms of content, the Artemis Accords aim at implementing the provisions of the Outer Space Treaty. ${ }^{9}$ They thus establish a set of guidelines intended to foster best practices for the human exploration of celestial bodiesnamely, peaceful uses of outer space, transparency, interoperability, assistance to personnel in outer space, registration of space objects, release of scientific data, preservation of outer space heritage, utilisation of space resources, deconfliction of space activities and sustainable use of outer space. ${ }^{10}$ In terms of legal significance, formally the Artemis Accords are not binding. ${ }^{11}$

For the sake of exposition, the provisions of the Artemis Accords can be grouped into three categories. The first category simply transposes provisions of the Outer Space Treaty into the text of the Artemis Accords. The second category implements provisions of the Outer Space Treaty, adding detail and clarity to the rights and obligations contained therein. The third category introduces new concepts. The explicit commitment of the signatories to operate within the boundaries of the Outer Space Treaty's principles makes the content of the Artemis Accords relatively uncontentious. However, a closer scrutiny reveals that certain provisions of the Artemis Accords go a

9 Artemis Accords (n 2) Preamble para 10 (also referring to 'other international instruments').

10 ibid Preamble, para 5.

11 Para 10 of the Preamble states that they are intended to 'establish a political understanding regarding mutually beneficial practices [among the signatories] for the future exploration and use of outer space, with a focus on activities conducted in support of the Artemis Program'. Section 13.2 further states that, unlike treaties, the Artemis Accords are not eligible for registration under art 102 of the Charter of the United Nations. 
step further than mere implementation, effectively introducing concepts and principles not mentioned in the Outer Space Treaty, thus raising issues of compatibility.

In the following subsections, the article examines the three categories of provisions contained in the Artemis Accords with a view to determining the extent to which they depart from consolidated principles of international space law. Firstly, it evaluates the provisions of the Artemis Accords incorporating provisions of the Outer Space Treaty and other relevant international law instruments (subsection A). It then analyses the provisions of the Artemis Accords adding detail to provisions of the Outer Space Treaty and other international instruments with a view to establishing whether they constitute subsequent practice within the meaning of Article 31 of the Vienna Convention on the Law of Treaties (VCLT) ${ }^{12}$ (subsection B). Finally, it evaluates the provisions of the Artemis Accords introducing new legal concepts (subsection C).

\section{A. Incorporating International Law Provisions}

The provisions of the Artemis Accords incorporating those of the Outer Space Treaty and other international instruments can be clustered, in turn, into three types. The first type includes verbatim transpositions of provisions of the Outer Space Treaty into the text of the Artemis Accords. For instance, Section 3 of the Artemis Accords states that any activity carried out by the signatories shall be 'exclusively for peaceful purposes', thus replicating the provision contained in Article IV, paragraph 2, of the Outer Space Treaty. ${ }^{13}$ Section 3 of the Artemis Accords also requires that the signatories carry out their activities 'in accordance with international law', thus mirroring the provision contained in Article III of the Outer Space Treaty. ${ }^{14}$ Likewise, Section 6 of the Artemis Accords requires the signatories to 'render necessary assistance to personnel in outer space who are in distress', thus replicating the obligation under Article V of the Outer Space Treaty. ${ }^{15}$ This type of provisions is uncontroversial.

The second type consists of provisions that cite articles of the Outer Space Treaty instead of replicating their content. For example, Section 4 of the Artemis Accords requires the signatory States to share scientific information resulting from their space activities with the public and the scientific community on a good faith basis and 'consistent with Article XI of the Outer Space Treaty' - that is to say, providing the details of the nature, conduct and

\footnotetext{
12 Vienna Convention on the Law of Treaties (adopted 23 May 1969, entered into force 27 January 1980) 1155 UNTS 331.

13 Outer Space Treaty (n 7) art IV, para 2 ('The Moon and other celestial bodies shall be used by all States Parties to the Treaty exclusively for peaceful purposes.' (emphasis added)).

${ }^{14}$ See also Outer Space Treaty (n 7) art I, para 2 ('Outer space, including the Moon and other celestial bodies, shall be free for exploration and use by all states ... in accordance with international law.' (emphasis added)).

${ }^{15}$ Outer Space Treaty (n 7) art V, para 1.
} 
locations of such activities. ${ }^{16}$ This type of provisions, like the first one, does not add any right or obligation to States that are not already contemplated in the Outer Space Treaty. Hence, it is uncontroversial.

The third type includes provisions of the Artemis Accords loosely related to the text of the Outer Space Treaty, but nonetheless grounded on international law instruments. For example, Section 4 of the Artemis Accords requires the signatory States to adopt standards that will ensure the interoperability of any infrastructure used for space-based exploration. The provision reflects established practice in the field of international cooperation in outer space, dating back to the historic docking of the joint Apollo-Soyuz mission in 1975. ${ }^{17}$ The rationale behind the requirement of standardisation of the space infrastructure lies predominantly in humanitarian considerations - namely, the ability to provide assistance to the personnel of other States in distress. In this respect, the provision of Section 5 of the Artemis Accords also relates to Article V, paragraph 2, of the Outer Space Treaty, which requires astronauts to 'render all possible assistance to the other astronauts of the other States Parties'.

Another example is the provision on registration of space objects contained in Section 7 of the Artemis Accords. Registration of space objects allows the identification of States and international organisations operating in outer space. By requiring the signatory States to determine which of them should register any relevant space object, the Artemis Accords indirectly refer to the provisions of Article V (return of space objects and astronauts in the event of accident, distress or emergency landing) and Article VII (liability of the launching State for damage caused by the space object) of the Outer Space Treaty. Finally, Section 12 of the Artemis Accords requires the signatories to include a plan for space debris mitigation in bilateral agreements. Space debris is a phenomenon caused by the growing number of satellites orbiting the Earth. As such, it is not contemplated by the provisions of the Outer Space Treaty. Nevertheless, the provisions of Section 12 of the Artemis Accords may be related to, and interpreted in the light of, the duties of States to conduct space activities 'with due regard to the corresponding interests' of other States set forth in Article IX of the Outer Space Treaty. Overall, this type of provisions of the Artemis Accords does not depart from established international practice. As a result, it remains uncontroversial.

\section{B. Refining International Law Provisions}

Two sections of the Artemis Accords contain provisions aimed at operationalising corresponding obligations found in the Outer Space Treaty

16 Art XI of the Outer Space Treaty (n 7) requires States to notify the UN Secretary-General, in addition to the public and the scientific community. Arguably this obligation applies to the activities conducted pursuant to the Artemis Accords by virtue of the reference to art XI of the Outer Space Treaty in Section 4 thereof.

${ }^{17}$ L Lebedev and A Romanov, Rendezvous in Space: Soyuz-Apollo (Central Books 1979). 
by clarifying the conduct required of States and other actors operating in outer space. This raises the question of whether the conclusion of the Artemis Accords amounts to subsequent practice within the meaning of Article 31(3) (b) of the VCLT - that is to say, for the purposes of treaty interpretation. Subsection I examines this issue by determining whether the provisions of Section 10 of the Artemis Accords (Space Resources) amount to subsequent practice in relation to the relevant provisions of the Outer Space Treaty. Subsection 2 performs the same task by focusing on the provisions of Section 11 of the Artemis Accords (Deconfliction of Space Activities).

\section{Provisions on space resources}

Subsequent practice may play a decisive role in clarifying the provisions of the Outer Space Treaty, which was adopted in 1967-a time when the space technology was still in its infancy - and contains provisions establishing basic principles of international space law. For instance, Article II thereof states that: 'Outer space, including the moon and other celestial bodies, is not subject to national appropriation by claim of sovereignty, by means of use or occupation, or by any other means.' Half a century after the adoption of the Outer Space Treaty, space technology has significantly advanced and space technology applications have become a common feature of everyday life. In light of this, Danilenko argues that new space activities require the adoption of more specific and detailed rules. ${ }^{18} \mathrm{~A}$ passage from the work of the International Law Commission (ILC) Study Group on Treaties over Time is also noteworthy. It reads:

As important treaties reach a certain age ... the context in which they operate becomes different from the one in which they were conceived. [...] The parties to a treaty normally wish to preserve their agreement, albeit in a manner which conforms to present day exigencies. Subsequent agreement and subsequent practice aim at finding a flexible approach to treaty application and interpretation, one that is at the same time rational and predictable. ${ }^{19}$

In this context, the interpretation of the principle of non-appropriation set forth in Article II of the Outer Space Treaty is the subject of Section 10 of the Artemis Accords, which concerns the extraction and utilisation of space resources. Paragraph 1 of the latter states that 'the utilisation of space resources can benefit humankind by providing critical support for safe and sustainable operations'. The provision appears to refer to the utilisation of space resources in situ to support scientific operations whose findings will be shared with the public and the scientific community. In this respect, it is in line with the provisions of the Outer Space Treaty stating that the exploration

\footnotetext{
18 GM Danilenko, 'International Lawmaking for Outer Space' (2016) 37 Space Policy 179.

19 Yearbook of the International Law Commission 2008 (United Nations 2008) vol II (2), Annex I, 154, para 14 (emphasis added).
} 
and use of outer space shall be carried out for the benefit and in the interests of all countries $^{20}$ and that States must facilitate international cooperation in the field of scientific investigation. ${ }^{21}$

However, Section 10, paragraph 2, of the Artemis Accords provides a peculiar interpretation of the principle of non-appropriation of celestial bodies contained in Article II of the Outer Space Treaty by stating that 'the extraction of space resources does not inherently constitute national appropriation'. ${ }^{22}$ The same provision establishes that 'contracts and other legal instruments relating to space resources should be consistent with the [Outer Space] Treaty'. Arguably, the reference in this second quotation is to Article VI of the Outer Space Treaty requiring States to authorise and provide continuing supervision to private actors performing activities in outer space. In my view, the element of novelty introduced here by the Artemis Accords is the clarification of the term 'national appropriation' contained in the Outer Space Treaty.

Indeed, the Outer Space Treaty is a compromise agreement which has been ratified by 110 States, including the spacefaring powers. ${ }^{23}$ This raises the question of whether giving a specific meaning to the term national appropriation in Section 10, paragraph 2, of the Artemis Accords amounts to a new interpretation of Article II of the Outer Space Treaty in a context different from the one in which it was adopted.

The ILC considers subsequent practice as an authentic means of interpretation, ${ }^{24}$ provided that it falls within the meaning of Article 31(3)(b) of the VCLT. The definition provided reads:

[Subsequent practice as an authentic means of treaty interpretation] consists of conduct in the application of a treaty, after its conclusion, which establishes the agreement of the parties regarding the interpretation of the treaty. ${ }^{25}$

20 Outer Space Treaty (n 7) art I, para 1.

21 ibid para 3.

22 This appears to be an accepted interpretation in the scholarly literature as well. For an analysis, see J Su, 'Legality of Unilateral Exploitation of Space Resources under International Law' (2017) 66 ICLQ 991 (arguing that neither treaty law nor customary international law prohibits as such the exploitation of natural resources by private actors); P De Man, Exclusive Use in an Inclusive Environment: The Meaning of the Non-Appropriation Principle for Space Resource Exploitation (Springer 2016) $287 \mathrm{ff}$ (with a focus on asteroid mining). Contrary views are often expressed by delegations at the UN Committee on the Peaceful Uses of Outer Space. See, for instance, 'Report of the Legal Subcommittee on its fifty-sixth session, held in Vienna from 27 March to 7 April 2017' (18 April 2017) UN Doc A/AC.105/1122, at 33, para 250 ('the unilateral action of individual States to promote their national private commercial interests or to allow "the flag of convenience" approach for corporate structures to exploit outer space resources is unacceptable').

23 In addition, the Outer Space Treaty has been signed by 23 States (1 January 2020); data available at $<$ TreatiesStatus-2020E.pdf (unoosa.org) $>$.

${ }^{24}$ ILC, 'Report of the International Law Commission on the Work of its Seventieth Session' (30 April-1 June and 2 July-10 August 2018) UN Doc A/73/10, at 23, Conclusion 3; Yearbook (n 19); ILC, 'Report of the International Law Commission on the Work of its Eighteenth Session' (4 May19 July 1966) UN Doc A/6309/Rev.1, at 52, para 15 (also stating that subsequent practice 'constitutes objective evidence of the understanding of the parties as to the meaning of the treaty').

${ }^{25}$ ILC, 'Report of the International Law Commission on the Work of its Seventieth Session' (n 24) 27, Conclusion 4, para 2. 
The definition contains two elements: conduct in the application of a treaty and the agreement between the parties stemming from that conduct. Accordingly, it is advisable to ascertain the presence of the two elements separately in order to establish whether the signing of the Artemis Accords by eight States amounts to subsequent practice able to modify the interpretation of the term 'national appropriation' contained in Article II of the Outer Space Treaty. ${ }^{26}$

First, in relation to conduct, the identification of the relevant subsequent practice requires a determination as to whether the parties have taken a position regarding the interpretation of the treaty. ${ }^{27}$ The ILC has clarified that '[s]uch position is not taken if the parties have merely agreed ... to establish a practical arrangement (modus vivendi) '. ${ }^{28}$ In my view, nothing in the conclusion of the Artemis Accords points to an agreement between the parties regarding the interpretation of the Outer Space Treaty. Nor does the text of the Artemis Accords refer to it, thus suggesting that the signatory States have agreed to establish a modus vivendi through the conclusion of subsequent bilateral agreements. It follows that the signatories to the Artemis Accords do not intend to amend or modify the Outer Space Treaty through conduct. ${ }^{29}$ This is not to say that subsequent practice is irrelevant for the purposes of treaty interpretation. Quite the contrary, it may constitute a supplementary means of interpretation under Article 32 of the VCLT.

In this respect, the weight to be attributed to subsequent practice may be assessed against two criteria. The first criterion consists of clarity and specificity of the practice at hand. ${ }^{30}$ Applied to Section 10, paragraph 2, of the Artemis Accords, it seems that the textual formulation of the provision presents an element of circular reasoning. Specifically, it states that the extraction and utilisation of space resources 'should be executed in a manner that complies with the Outer Space Treaty'. ${ }^{31}$ In my view, while containing a clear instruction, the provision lacks specificity. The further assertion that 'the extraction of space resources does not inherently constitute national appropriation' 32 simply endorses one of the possible interpretations of the Outer Space Treaty (impliedly stating that the specific arrangements for extraction of natural resources — as detailed in the envisaged bilateral agreements — will be

\footnotetext{
26 As a political agreement, the Artemis Accords can be considered subsequent practice for the purposes of interpretation. See United States-United Kingdom Arbitration concerning Heathrow Airport User Charges (United States v United Kingdom) (1992) 24 RIAA 1, ch 6, paras 6.7-6.8 (recognising a Memorandum of Understanding between the US and the UK as "consensual subsequent practice'); A Aust, Modern Treaty Law and Practice (3rd edn, Cambridge University Press 2013) 214-16.

27 ILC, 'Report of the International Law Commission on the Work of its Seventieth Session' (n 24) 43, Conclusion 6, para 1.

30 ibid 70, Conclusion 9, para 1.

28 ibid.

29 ibid 51, Conclusion 7, para 3.

32 ibid (emphasis added).
} 
the determining factor of the lawfulness of that activity under the Outer Space Treaty). ${ }^{33}$ As a result, the Artemis Accords do not satisfy the first criterion.

The second criterion concerns the repetition of the practice over time. ${ }^{34}$ As things stand, the Artemis Accords have been signed by eight States comprising established and emerging spacefaring States alike. In the light of the number of States Parties to the Outer Space Treaty, ${ }^{35}$ the figure is neither decisive nor insignificant for the purposes of treaty interpretation, ${ }^{36}$ since the Artemis Accords will form the basis of further partnerships between NASA and any other State willing to contribute to the realisation of the Artemis Program. It thus appears that the weight of the Artemis Accords as subsequent practice must be considered in perspective and reassessed at a later stage. Eight signatures do not as such carry a heavy weight. This further suggests that the Artemis Accords do not satisfy the second criterion.

The second element of the definition of subsequent practice as an authentic means of treaty interpretation is the agreement of the parties regarding the interpretation of the treaty. The ILC clarified that an agreement under Article 31(3)(b) of the VCLT 'requires a common understanding regarding the interpretation of a treaty which the parties are aware of and accept'. ${ }^{37}$ The text of the Artemis Accords is unequivocal on this point, as it states that: 'The Signatories affirm that the extraction of space resources does not inherently constitute national appropriation under Article II of the Outer Space Treaty.' 38 Therefore, it may be concluded that they contain a common understanding. Yet the contours of that understanding lack clarity and specificity, since the provisions of Section 10, paragraph 2, of the Artemis Accords do not contain any guidance as to the required, or simply suggested, modality of resource extraction other than the statement that 'contracts and other legal instruments relating to space resources should be consistent with [the Outer Space Treaty]'.

Based on the considerations above, it is argued that, as a form of subsequent practice, Section 10 of the Artemis Accords does not represent an authentic interpretation of Article II of the Outer Space Treaty. Nor does it aim to change or modify existing interpretations thereof. Silence of one or more parties to the Outer Space Treaty may constitute acceptance of the

33 cf S Freeland and R Jakhu, 'Article II' in S Hobe, B Schmidt-Tedd and K Schrogl (eds), Cologne Commentary on Space Law (Verlag 2009) vol I, 60, para 67 (casting doubt about the lawfulness of space resource activities in the absence of a bespoke international framework).

34 ILC, 'Report of the International Law Commission on the Work of its Seventieth Session' (n 24) 70, Conclusion 9, para 2 ('whether and how [practice] is repeated'). 35 (n 23)

36 WTO, EC-Computer Equipment, Appellate Body Report, WT/DS62/AB/R, WT/DS67/AB/ $\mathrm{R}$ and WT/DS68/AB/R (22 June 1998) para 93 ('the prior practice of only one of the parties may be relevant, but it is clearly of more limited value than the practice of all parties' (emphasis original)).

37 ILC, 'Report of the International Law Commission on the Work of its Seventieth Session' (n 24) 75, Conclusion 10, para 1.

38 Artemis Accords (n 2) Section 10, para 2 (emphasis added). 
subsequent practice induced by the implementation of the Artemis Accords, ${ }^{39}$ potentially contributing to the formation of opinio juris relevant for the creation of a customary rule. However, given the negative reaction of spacefaring powers like Russia and China to the conclusion of the Artemis Accords, ${ }^{40}$ for the time being this does not appear a realistic perspective.

\section{Deconfliction of space activities}

Section 11 of the Artemis Accords deals with the issue of deconfliction of space activities. Paragraphs 3 and 4 thereof refer to two principles set forth in Article IX of the Outer Space Treaty - namely, the principle that States should conduct their activities in outer space with due regard to the corresponding interests of the other States Parties to the treaty and the duty to avoid harmful interference with activities of other States Parties. In order to operationalise such principles, Section 11, paragraph 5, of the Artemis Accords requires the signatories to provide each other with the 'necessary information regarding location and nature' of their activities and create a 'safety zone' to avoid potential harmful interference ${ }^{41}$ Conceived as temporary ${ }^{42}$ safety zones serve two purposes. First, they aim at facilitating scientific discovery. Secondly, building on the provisions of Section 10 of the Artemis Accords, they represent a means for facilitating 'the safe and efficient extraction and utilization of space resources in support of sustainable space exploration and other operations'.

Most notably, the concept of a safety zone is not mentioned in the Outer Space Treaty. In this respect, its introduction in Section 11 of the Artemis Accords represents a genuine innovation. At the same time, it is not an entirely new concept in the field of space law. ${ }^{43}$ For instance, it has been discussed by the Hague International Space Resources Governance Working Group (hereinafter the Hague Working Group) as a means to ensure the long-term sustainability of

39 Case Concerning the Temple of Preah Vihear (Cambodia v Thailand) (Merits) [1962] ICJ Rep 6, 23 (recognising the possibility of expressing agreement regarding interpretation by silence or inaction). See also ILC, 'Report of the International Law Commission on the Work of its Seventieth Session' (n 24) 75, Conclusion 10, para 2 ('Silence on part of one or more parties may constitute acceptance of the subsequent practice when the circumstances call for some reaction.'); WTO, EC-Chicken Cuts, Appellate Body Report, WT/DS269/AB/R and WT/ DS286/AB/R (27 September 2005) para 272 (referring to lack of reaction or silence by a treaty party as possible acceptance of the practice of other parties).

40 As discussed in Section I above.

41 Artemis Accords (n 2) Section 11, para 7 (describing a safety zone as "the area in which nominal operations of a relevant activity or an anomalous event could reasonably cause harmful interference').

42 ibid Section 11, para 7(c).

43 See, for instance, Law of the Russian Federation on Space Activities (20 August 1993) No 5663-I (as amended by Federal Law No 54-03, 15 April 2019) art 17, para 5 ('In the immediate vicinity of a space object of the Russian Federation within the bounds of a zone minimally necessary for the guarantee of safety of space activity, rules may be established which are obligatory for Russian and foreign organizations and citizens.' (emphasis added)). The concept of safety zone also features in other areas of international law, such as the law of the sea and international humanitarian law. For an overview, see T Desch, 'Safety Zones' MPEPIL (2015). 
outer space. ${ }^{44}$ The latter is a concept also mentioned in Section 11, paragraph 2, of the Artemis Accords, which refers to the UN Guidelines for the Long-term Sustainability of Outer Space (2019). ${ }^{45}$ This raises the question of whether the provisions of Section 11 of the Artemis Accords constitute subsequent practice under Article 31(3)(b) of the VCLT - that is to say, whether they are an authoritative interpretation of the Outer Space Treaty.

In terms of conduct, ${ }^{46}$ Section 11, paragraph 7, of the Artemis Accords establishes four principles guiding the creation of safety zones that the signatories have committed to observe. They relate to size, scope and duration of safety zones, and are further complemented by provisions on information disclosure, ${ }^{47}$ advance notification of the operations ${ }^{48}$ and periodic consultations with the other parties. ${ }^{49}$ In this respect, the provisions of Section 11 appear to be both clear and specific. They also seem to be amenable to systematic repetition over time, ${ }^{50}$ since the signatory States have explicitly and unequivocally committed to them without any specific time limit.

Equally, it is noteworthy that the creation of safety zones is only one of a range of possible ways to avoid harmful interference. As a result, the provisions of Section 11 of the Artemis Accords do not widen or restrict the scope of Article IX of the Outer Space Treaty. They nonetheless add detail and clarity to the text of the Outer Space Treaty, eventually introducing an element of innovation. From this limited perspective, they appear to fulfil the criteria of subsequent practice under Article $31(3)(\mathrm{b})$ of the VCLT. ${ }^{51}$ A possible counterargument is that, being the Artemis Accords an initiative of the US, such subsequent practice does not reflect the agreement of all the States Parties to the Outer Space Treaty. This type of objection has a precedent in international practice. For instance, ICSID tribunals have recognised that 'the view of one State does not make international law'. 52 Similarly, in Japan: Alcoholic Beverages II, the WTO Appellate Body held that: 'An isolated act is generally not sufficient to establish subsequent practice; it is a sequence of acts establishing the agreement of the parties that is relevant.' 53

44 O Bittencourt Neto et al (eds), Building Blocks for the Development of an International Framework for the Governance of Space Resource Activities: A Commentary (Eleven 2020) 58, Building Block 10.

46 As discussed in Section II.B.1 above.

48 ibid para 10.

${ }^{45}$ UN Doc A/74/20, Annex II. 47 Artemis Accords (n 2) Section 11, para 9. 49 ibid para 11.

50 ILC, 'Report of the International Law Commission on the Work of its Seventieth Session' (n 24) 70 , Conclusion 9, para 2.

51 See also ibid 51, Conclusion 7, para 1 (referring to subsequent practice under the meaning of art 31(3) of the VCLT as capable of contributing to the clarification of the meaning of a treaty).

52 Sempra Energy International v Argentine Republic, ICSID Case No ARB/02/16 (28 September 2007) para 385; Enron Corporation and Ponderosa Assets LP v Argentine Republic, ICSID Case No ARB/01/3 (22 May 2007) para 337; Philip Morris Brands SÁRL, Philip Morris Products SA and Abal Hermanos SA v Oriental Republic of Uruguay, ICSID Case No ARB/10/7 (28 June 2016) para 476.

${ }_{53}$ Japan: Alcoholic Beverages II, Report of the Appellate Body, WT/DS8/AB/R, WT/DS10/ $\mathrm{AB} / \mathrm{R}$ and WT/DS11/AB/R (1 November 1996) Section E, 13. 
The argument above has merit, since the bilateral agreements incorporating the Artemis Accords are yet to be concluded. ${ }^{54}$ Much remains to be seen about the extent to which the concept of safety zones will be embraced by the nascent space mining industry as well. Therefore, from this limited perspective, it can be concluded that the Artemis Accords may be regarded as emerging subsequent practice under Article 32 of the VCLT - that is to say, conduct by one or more parties in the application of the Outer Space Treaty carrying the value of supplementary, as opposed to authentic, means of interpretation. ${ }^{55}$ Subsequent practice under Article 32 of the VCLT does not require the agreement of all the parties to a treaty. ${ }^{56}$ Given the open resistance to the Artemis Accords by a number of States Parties to the Outer Space Treaty, this latter perspective appears to be preferred. ${ }^{57}$

\section{Introducing New Concepts}

Section 9 of the Artemis Accords introduces a novel concept in international space law-namely, the preservation of outer space heritage. Assuming the existence of a collective interest in its preservation, ${ }^{58}$ outer space heritage is described as any 'historically significant human or robotic landing site, artifact, spacecraft, and other evidence of activity on celestial bodies' which the signatories have agreed to preserve 'in accordance with mutually developed standards and practices'. ${ }^{59}$ There is no provision in the Outer Space Treaty under which the concept of space heritage neatly falls. The closest provision is Article 7, paragraph 3, of the Moon Agreement. It reads:

States Parties shall report to other States Parties and to the Secretary-General concerning areas of the Moon having special scientific interest in order that, without prejudice to the rights of the other States Parties, consideration may be given to the designation of such areas as international scientific preserves for which special protective arrangements are to be agreed upon in consultation with the competent bodies of the United Nations. ${ }^{60}$

${ }^{54}$ ibid 12-13 ('subsequent practice in interpreting a treaty has been recognized as a "concordant, common and consistent" sequence of acts or pronouncements which is sufficient to establish a discernible pattern implying the argument of the parties regarding its interpretation').

${ }^{55}$ In the commentary to the Draft Articles on the Law of Treaties, the ILC pointed out that 'the practice of individual states in the application of a treaty ... may be taken into account only as one of the further means of interpretation mentioned in Article [32 of the VCLT]'. Yearbook of the International Law Commission 1966 (United Nations 1966) vol II, 222, para 15. See also ILC, 'Report of the International Law Commission on the Work of its Seventieth Session' (n 24) 27, Conclusion 4, para $3 . \quad{ }_{56}$ ibid Commentary to Draft Conclusion 4, 33, para 23.

${ }_{57}$ EC-Computer Equipment (n 36) para 95 (arguing that conflicting positions expressed by different parties to a treaty preclude the existence of an agreement).

${ }^{58}$ Artemis Accords (n 2) Preamble, para 8.

59 ibid Section 9, para 1.

${ }^{60}$ Agreement Governing the Activities of States on the Moon and Other Celestial Bodies (adopted 18 December 1979, entered into force 11 July 1984) 1363 UNTS 3 (Moon Agreement) (emphasis added). 
It may be argued that, if the creation by special agreement of international scientific preserves does not violate the principle of free exploration and use of celestial bodies, by analogy the same applies to the creation of international historical and cultural preserves. Section 9, paragraph 2, of the Artemis Accords appears to support the analogy by requiring the signatory States to engage in multilateral efforts to develop rules aimed at preserving outer space heritage. In practice, protecting sites and artifacts of historic value on the surface of the Moon (and, in perspective, other celestial bodies) entails the creation of a safety zone in order to prevent the plume effect. ${ }^{61}$ The main difference between the creation of a safety zone for the purpose of facilitating the utilisation of the natural resources of celestial bodies and the creation of a safety zone for the purpose of protecting human heritage in outer space is that the latter would create a deconfliction zone aimed at preventing harm to landing sites and non-operational objects, such as artifacts, rather than human beings. ${ }^{62}$

As objects launched into outer space, human artifacts and spacecraft remain property of the State that placed them on a celestial body. ${ }^{63}$ An example is the flag planted by the Apollo 11 mission in 1969 or the Chinese flag planted by the Chang'e 5 mission in 2020. It is unclear whether the same considerations apply to the status of 'other evidence of activity on a celestial body', ${ }^{64}$ such as Neil Armstrong's boot prints on the landing site of the 1969 Apollo 11 mission or the tracks of the Lunar Roving Vehicle used by the Apollo 15 mission in 1971. The Outer Space Treaty does not provide any criteria that may help qualify relevant objects with historical value as outer space heritage. Nor does the UNESCO World Heritage Convention, ${ }^{65}$ since Article 4 thereof provides that States can identify and preserve only objects situated on their territory. Taken at face value, this provision clashes with the principle of non-appropriation set forth in Article II of the Outer Space Treaty. As a result, the Artemis Accords recognise that States should engage in multilateral efforts aimed at elaborating a definition of outer space heritage and related criteria for identification. ${ }^{66}$

In this context, the signatories to the Artemis Accords can only assume that certain human and robotic artifacts possess significant historical value and treat them accordingly by establishing a safety zone around the objects potentially

61 The plume effect is the blowing of lunar soil, including rocks and dust, around large areas of the Moon's surface mainly caused by the engine exhaust of lunar landers. See MLD Hanlon and B Cunningham, "The Legal Imperative to Mitigate the Plume Effect: An "Aggravation and Frustration" That Imperils Our History and Our Future' (2019) 43 Journal of Space Law 309, $316-17$ and 319.

${ }^{62}$ NASA's Recommendations to Space-Faring Entities: How to Protect and Preserve the Historic and Scientific Value of U.S. Government Lunar Artifacts (July 2011) 7 (recommending a two-kilometre radius).

63 Outer Space Treaty (n 7) art VIII.

${ }_{65}$ Artemis Accords (n 2) Section 9, para 1.

65 UNESCO, Convention Concerning the Protection of the World Cultural and Natural Heritage (adopted 16 November 1972, entered into force 17 December 1975) 1037 UNTS 151, art 4.

66 Artemis Accords (n 2) Section 9, para 2. 
affected by the plume effect or other harmful activities. An argument is therefore made that causing damage to an object recognised of having historic value for humankind would trigger State responsibility for violation of the principle of due regard to corresponding interests of other States set forth in Article IX of the Outer Space Treaty.

However, as an obligation of conduct, it is not clear which elements constitute the benchmarks for assessing a violation of the principle of due regard. So far, only two international tribunals have referred to it in context of law of the sea disputes. ${ }^{67}$ In particular, in the Chagos case, the arbitral tribunal held that the principle of due regard acquires meaning in relation to the circumstances of the case and the nature of the rights involved. ${ }^{68}$ As a result, it declined to find 'any universal rule of conduct'. ${ }^{69}$ Equally, it is not clear what sort of reparation the damage to heritage in outer space would entail. ${ }^{70}$ On the one hand, due to the nature of the objects at hand, it seems unlikely that States would be able to return the object to its initial condition or replace it. On the other hand, determining the amount of compensation as well as the beneficiaries of such compensation is likely to pose new challenges to States conducting activities in outer space under the Artemis Accords.

In light of the above, it appears that the concept of heritage in outer space is not incompatible with the provisions of the Outer Space Treaty, although the latter are inadequate to provide effective protection and need to be supplemented by bespoke rules widely accepted by the international community. In this respect, Section 9 of the Artemis Accords appears to be a significant innovation compared to the provisions of the Outer Space Treaty.

\section{IMPACT OF THE ARTEMIS ACCORDS ON THE DEVELOPMENT OF INTERNATIONAL}

SPACE LAW

From a substantive point of view, the Artemis Accords appear to be grounded on established principles of international space law and, in particular, the provisions of the Outer Space Treaty. In this respect, they are innovative but not revolutionary. However, from a formal perspective, they noticeably depart from the practice of negotiating the governing principles of international space law within the United Nations. Therefore, this section evaluates the impact of the Artemis Accords on the development of international space law by determining whether their process of adoption amounts to a potentially new model for outer space law-making.

67 Chagos Marine Protected Area Arbitration (Mauritius v UK), PCA Case No 2011-03, Award (18 March 2015) para 519; The M/V 'Norstar' Case (Panama v Italy) (Judgment of 10 April 2019) ITLOS Case No 25, para 214 (denying the violation of the principle of due regard in the case at hand without discussing the criteria for assessment). $\quad 68$ Chagos (n 67). $\quad 69$ ibid.

70 UNGA Res 56/83 'Responsibility of States for Internationally Wrongful Acts' (12 December 2001) UN Doc A/RES/56/83, Annex, art 31, para 1 ('The responsible State is under an obligation to make full reparation for the injury caused by the internationally wrongful act.'). 
The starting point of the analysis is that the UN treaties on outer space have been adopted in the 1960s and 1970s at the height of the Cold War confrontation between the US and the Soviet Union and reflect the mutually acceptable compromise between the two ideological blocs. ${ }^{71}$ In the absence of any previous regulation in this field and mindful of the fact that the technology used to perform space activities can accommodate both peaceful and nonpeaceful purposes, ${ }^{72}$ the UN space treaties attempt to regulate any future activity of States in outer space by establishing broad principles. In this respect, they represent the hallmark of the anticipatory character of space regulation.

Technically, anticipatory regulation consists of producing rules aimed at governing situations that may arise only in the future. ${ }^{73}$ As Danilenko writes:

While anticipatory regulation may be useful for the establishment of a broad legal framework for future state activities, it is dangerous to rely on it too heavily in cases where detailed regulation of complex technical or economic issues is required. ${ }^{74}$

Indeed, with the advent of globalisation, the scope of outer space activities has acquired a whole new dimension. As a result of scientific and technological advances, the provisions of the UN outer space treaties appear increasingly in need of refinement in order to be able to govern new activities in outer space, both scientific and commercial. ${ }^{75}$ In particular, the emergence of private actors as full-fledged participants in the exploration and use of outer space has determined a shift of emphasis from multilateral fora such as COPUOS to the domestic forum as the preferred setting for States to develop their space policies. ${ }^{76}$ This trend is most noticeable in the regulation of space resource activities. For instance, the US and Luxembourg have dedicated legislation conferring property rights to companies mining outer space resources. ${ }^{77} \mathrm{Such}$ States claim to be acting within the boundaries of the multilateral treaties on outer space that they have ratified. ${ }^{78}$

71 Danilenko (n 18) 180 (arguing that space law developed in a 'confrontational context').

72 S Hobe, 'Historical Background' in Hobe, Schmidt-Tedd and Schrogl (n 33) 14, para 44.

73 Danilenko (n 18) 181. 74 ibid.

75 ibid

76 P De Man, 'State Practice, Domestic Legislation and the Interpretation of Fundamental Principles of International Space Law' (2017) 42 Space Policy 92, 101 (pointing out 'a marked shift in lawmaking dynamics from the multilateral to the domestic level'). See also K-U Schrogl, 'The New Debate on the Working Methods of the UNCOPUOS Legal Subcommittee' (2014) 105 Acta Astronautica 101 (pointing out the diminishing role of the legal sub-committee 'as the highest body in space lawmaking'); K-U Schrogl, 'Is UNCOPUOS Fit for the Future?' (2011) 60 German Journal of Air and Space Law 93 (arguing that COPUOS reached its low point in the 1990s).

77 US Commercial Space Launch Competitiveness Act, Public Law 114-90 (25 November 2015); Law of 20 July 2017 on the Exploration and Use of Space Resources, Official Journal, Mémorial A No 674 (28 July 2017).

78 cf S Hobe and P De Man, 'National Appropriation of Outer Space and State Jurisdiction to Regulate the Exploitation, Regulation and Utilization of Space Resources' (2017) 66 German Journal of Air and Space Law 460, 475 (denying the legal character altogether of such pieces of legislation). 
In this context, the Artemis Accords turn out to be the cusp of a wider trend in the law-making process for outer space, sitting at the crossroads of multilateralism and unilateral national legislation. Aimed at establishing a core of principles to be included in future bilateral agreements between NASA and each signatory State, they spell out the basis for subsequent agreements without providing the details of such agreements. At the same time, their broad provisions are forward-looking, for they require the signatories to perform actions the regulation of which are the subject of future multilateral negotiation. In doing so, they depart from the anticipatory approach to regulation of outer space activities endorsed by the UN outer space treaties.

This suggests that the Artemis Accords are an instrument of space governance rather than a mere set of rules. On the one hand, they do not aim at introducing any new principle of international space law. As discussed in Section II above, the Artemis Accords are rooted on the provisions of the Outer Space Treaty. On the other hand, they provide the blueprint for a model of governance of space resource activities. From this limited perspective, they partake in a broader trend consolidating the concept of staged governance for the exploitation of space resources.

The staged approach to space governance has been developed by the Hague Working Group. ${ }^{79}$ Led by a consortium of academic institutions, the project stands out for its openness in terms of stakeholders' representationgovernment representatives, civil society groups and space industries - and has concluded its work by issuing a set of guidelines. To a large extent, the provisions of the Artemis Accords align with the recommendations of the Hague Working Group, which are also known as the 'Building Blocks' ${ }^{80}$

The Building Blocks endorse the principle of adaptive governance. ${ }^{81}$ The latter is a form of environmental governance aimed at coordinating resource management regimes in situations of complexity and uncertainty determined by rapid environmental change. ${ }^{82} \mathrm{~A}$ concept of recent origin, ${ }^{83}$ adaptive governance recognises the existence of a link between social and ecological systems. Accordingly, it envisages the creation of frameworks of governance that are receptive of the feedbacks originating both in the social and ecological systems-hence, they continually evolve through adaptation. ${ }^{84}$ The implementation of an adaptive governance framework requires a range of interactions between institutions, networks and actors. Applied to the field

79 Bittencourt Neto (n 44).

80 ibid.

81 ibid 7.

82 BC Chaffin et al, 'A Decade of Adaptive Governance Scholarship: Synthesis and Future Directions' (2014) 19(3) Ecology and Society 56.

${ }^{84}$ For an overview of scholarly positions, see Chaffin et al. (n 82); T Yasmin, M Farrelly and BC Rogers, 'Adaptive Governance: A Catalyst for Advancing Sustainable Urban Transformation in the Global South' (2019) 36(5) International Journal of Water Resources Management 818. 
TABLe 1:

Comparison between the Artemis Accords and the Building Blocks

\begin{tabular}{|c|c|}
\hline ARTEMIS ACCORDS & BUILDING BLOCKS \\
\hline S.3-peaceful purposes & BB4.3(a) \\
\hline S.3 - accordance with international law & BB4.1 and BB4.3(d) \\
\hline $\begin{array}{l}\text { S. } 4 \text { - dissemination of information in good } \\
\text { faith }\end{array}$ & $\mathrm{BB} 13.1(\mathrm{~d})$ and BB14 \\
\hline S.5 - interoperability standards & BB11.2 \\
\hline S.6-assistance to personnel in distress & BB15 \\
\hline S. 7 - registration of space objects & BB14 \\
\hline $\begin{array}{l}\text { S. } 8 \text { - exemption from requirement of open } \\
\text { sharing of scientific data to protect private } \\
\text { operators }\end{array}$ & BB8 (indirect reference) and BB17 \\
\hline S.9-preserving outer space heritage & BB10(h), BB18(b)(iii) and BB18(c)(ii) \\
\hline $\begin{array}{l}\text { S. } 10 \text { - promoting sustainable space } \\
\text { activities }\end{array}$ & $\begin{array}{l}\mathrm{BB} 4(2)(\mathrm{f}-\mathrm{g}) \text { and } \mathrm{BB} 10 \mathrm{BB} 8 \text { (indirect } \\
\text { reference) and BB14 (indirect reference) }\end{array}$ \\
\hline $\begin{array}{l}\text { S. } 10 \text { - extraction of space resources does } \\
\text { not inherently constitute national } \\
\text { appropriation }\end{array}$ & N/A \\
\hline \multicolumn{2}{|l|}{$\begin{array}{l}\text { S.10 - informing the UN Secretary-General } \\
\text { and the international community of space } \\
\text { resource extraction }\end{array}$} \\
\hline $\begin{array}{l}\text { S.11 - long-term sustainability of outer } \\
\text { space }\end{array}$ & BB4(2)(f)BB9BB11BB17 \\
\hline \multicolumn{2}{|l|}{$\begin{array}{l}\text { S.11-due regard to the corresponding } \\
\text { interests of other States }\end{array}$} \\
\hline \multicolumn{2}{|l|}{ S.11-creation of safety zones } \\
\hline \multicolumn{2}{|l|}{$\begin{array}{l}\text { S.11 - protection of proprietary and export- } \\
\text { controlled information }\end{array}$} \\
\hline S. 12 - minimising orbital debris & BB10(f) \\
\hline $\begin{array}{l}\text { S. } 13 \text { - periodic review of the Artemis } \\
\text { Accords }\end{array}$ & BB20 \\
\hline
\end{tabular}

Comparison between the content of the Sections of the Artemis Accords (S) and the corresponding provisions of the Building Blocks (BB).

of space resource exploitation, reliance on the principle of adaptive governance entails a step-by-step, incremental approach to the regulation of space resource activities $^{85}$ involving all the relevant stakeholders. ${ }^{86}$

${ }^{85}$ Bittencourt Neto (n 44) 7 ('space resource activities should be incrementally addressed at the appropriate time on the basis of contemporary technology and practices'). See also ibid 103, Building Block 20 (recognising the need for periodic monitoring and review of the suggested international framework on space resource activities).

86 ibid 17-19, Commentary to Building Block 1, para 1 (referring to the need to create an enabling environment). 
A comparison between the provisions of the Artemis Accords and those of the Building Blocks shows the existence of a high degree of compatibility between the two instruments (Table 1). Moreover, the provisions of the Artemis Accords operationalising provisions of the Outer Space Treaty ${ }^{87}$ or introducing new concepts ${ }^{88}$ require the signatory States to engage in multilateral efforts to add further detail to those provisions. Specifically, they require States to use their experience to inform multilateral discussions and be receptive of the outcome thereof, thus creating the feedback effect characterising the concept of adaptive governance.

For instance, Section 10, paragraph 4, of the Artemis Accords provides that:

The Signatories intend to use their experience under the Accords to contribute to multilateral efforts to further develop international practices and rules applicable to the extraction and utilization of space resources, including through ongoing efforts at the COPUOS.

The provision above recalls Building Block 8.1, which states that rights over resources extracted from celestial bodies 'can lawfully be acquired through domestic legislation, bilateral agreements and/or multilateral agreement' ${ }^{89}$ Such rights must be mutually recognised by the parties and subsequently registered in order to ensure transparency. ${ }^{90}$ From this perspective, the process of definition of resource rights turns out to be a pragmatic one based on the actual practice of space operators, which both influences and is influenced by the outcome of discussions in different multilateral fora. The difference with the anticipatory approach to the regulation of space resource activities set forth in the Moon Agreement-which subordinates the exploitation of the natural resources of the moon to the conclusion of an international framework contemplating appropriate procedures for the material execution of mining activities - is striking. ${ }^{91}$

In a similar vein, Section 11, paragraph 6, of the Artemis Accords states that:

The Signatories intend to use their experience under the Accords to contribute to multilateral efforts to further develop international practices, criteria, and rules applicable to the definition and determination of safety zones and harmful interference.

As discussed in Section II.B.2 above, the Outer Space Treaty does not refer to the concept of safety zone. It only refers to the principle underlying the creation of safety zones - that is to say, avoiding harmful interference with

${ }^{87}$ As discussed in Section II.B above.

88 As discussed in Section II.C above.

${ }^{89}$ Envisioning proprietary rights over the extracted resources does not as such violate the principle of non-appropriation. The latter includes sovereignty rights and proprietary rights over a celestial body. See M Lachs, The Law of Outer Space: An Experience in Contemporary Law-Making (Nijhoff 2010) 42; V Pop, Who Owns the Moon? Extraterrestrial Aspects of Land and Mineral Resources Ownership (Springer 2008) 59-72; F Tronchetti, The Exploitation of Natural Resources of the Moon and Other Celestial Bodies: A Proposal for a Legal Regime (Nijhoff 2009) 218-31. $\quad 90$ As clarified in Bittencourt Neto (n 44) 79-80, Building Block 14.

${ }^{91}$ Moon Agreement (n 60) art 11, para 5. 
the activities of the other parties. ${ }^{92}$ Likewise, Building Block 11.3 encourages the establishment of safety zones 'to assure safety and avoid any harmful interference' with space resource activities. This further demonstrates that international practice is increasingly taken as the starting point, rather than the outcome, of multilateral discussions - in this case, discussions aimed at gathering consensus on the concept and regulation of safety zones. In doing so, the practice of actors operating in outer space remains open to the feedback originating in multilateral fora, thus adapting to new regulatory frameworks. ${ }^{93}$

Last but not least, Section 9 of the Artemis Accords invites the commencement of multilateral discussions to develop the concept of outer space heritage. ${ }^{94}$ It is also noteworthy that Building Blocks 10 and 18 refer several times to 'designated and internationally endorsed outer space natural or cultural heritage sites' with a view to protecting them against potentially harmful activities. ${ }^{95}$ This provides further evidence that, within an adaptive governance framework, practice is both the springboard for and the outcome of multilateral negotiation.

In light of the above, it is suggested that the endorsement of the principle of adaptive governance in the Artemis Accords has emerged as a new method of reaching international consensus on outer space activities. The main advantage of this new form of decision-making process is that it remains a speedy and flexible mechanism operating within the boundaries of the Outer Space Treaty. Another advantage is that it promotes collaboration, thus avoiding unilateralism. However, a possible downside is that, by giving prominence to the interests of spacefaring States, ${ }^{96}$ it may widen the gap between developed and developing countries in terms of benefit sharing stemming from the exploitation of outer space resources. In this sense, it may weaken genuine international cooperation eventually running counter the spirit of Article III of the Outer Space Treaty.

92 Outer Space Treaty (n 7) art IX.

93 For a contrary view, see Tronchetti (n 89) 236 (introducing a fully developed proposal for a treaty aimed at regulating 'all the foreseeable scenarios and legal problems that may emerge' in the course of exploitative activities by private actors); S Hobe, 'The Moon Agreement - Let's Use the Chance!' (2010) 59 German Journal of Air and Space Law 372 (advocating a revival of the Moon Agreement, including the adoption of the envisioned institutional framework); Schrogl 'Is UNCOPUOS Fit for the Future?' (n 76) 93 (arguing that COPUOS reached its low point in the 1990s).

94 Artemis Accords (n 2) Section 9, para 2 ('The Signatories intend to use their experience under the Accords to contribute to multilateral efforts to further develop international practices and rules applicable to preserving outer space heritage.').

${ }_{95}$ Similarly, the Vancouver Regulations recognise the need to preserve cultural heritage; Outer Space Institute, 'Vancouver Recommendations on Space Mining' (20 April 2020) Section VII, para 21.

96 F Xu and J Su, 'New Elements in the Hague Space Resources Governance Working Group's Building Blocks' (2020) 53 Space Policy 1, 7 ('Although consensus is and will continue to be the most effective solution, securing the positive support of the space-faring countries that are the most involved in space resource activities is a prerequisite for effective space legislation. The [Moon Agreement] was unsuccessful, as major space-faring nations refused to sign and ratify it.'). 
Most notably, the Artemis Accords do not refer to sharing of benefits stemming from outer space activities. Equally, they do not envision any institutional arrangement for the implementation and review of space governance frameworks. Nor do they contemplate a dispute settlement mechanism. At the moment, this is a significant flaw. Yet the signatories' commitment to multilateral efforts and periodic review ${ }^{97}$ of the text of the Artemis Accords does not preclude any change in that direction, thus accommodating the possibility of further evolution. In this respect, the Artemis Accords may benefit from developing along the lines of the Building Blocks, which are likely to form the basis of both national and international frameworks for the governance of space resource activities. ${ }^{98}$ I provide three examples.

First, Building Block 13 develops the concept of benefit sharing, which consists of actions aimed at promoting and facilitating space training and technology as well as joint ventures and exchange of expertise on a mutually acceptable basis. Most importantly, it calls for the creation of a voluntary international fund while excluding any forms of compulsory monetary sharing of benefits. In doing so, it moves away from the rigid interpretation of equitable sharing as equal sharing characterising the developing countries' original interpretation of celestial bodies as the common heritage of mankind. ${ }^{99}$ Since the provisions of Building Block 13 are compatible with the Outer Space Treaty and the Moon Agreement stipulating that 'the exploration and use of outer space, including the Moon and other celestial bodies, shall be carried out for the benefit and in the interests of all countries', ${ }^{100}$ they would accommodate the obligations of the signatories to the Artemis Accords, including those who have also signed or ratified the Moon Agreement.

Secondly, Building Block 18 outlines the basic functions that an international framework for the governance of space resource activities should serve. They include the creation and management of a registry for priority rights, a separate database providing information about various aspects of space resource activities - including advance notification and termination of such activities - as well as the establishment of an international body with the

97 Artemis Accords (n 2) Section 13.

$98 \mathrm{Xu}$ and $\mathrm{Su}$ (n 96) 7. It is also noteworthy that the adoption of the Building Blocks has generated mixed reactions within COPUOS; see 'Report of the Legal Subcommittee on its fiftyseventh session, held in Vienna from 9 to 20 April 2018' (30 April 2018) UN Doc A/AC.105/ 1177, at 30, para 234 (describing the Building Blocks as a valuable starting point for the negotiation of an international framework) and ibid para 233 (arguing that the Building Blocks 'should not be acknowledged as providing a forum for negotiation').

99 cf Vancouver Recommendations (n 95) Section VII, para 20 (favouring the establishment of a mandatory benefit sharing mechanism inclusive of monetary benefit sharing).

${ }_{100}$ Outer Space Treaty (n 7) art I, para 1; Moon Agreement (n 60) art 4, para 1. See also Moon Agreement (n 60) art 11, para 7(d) (stating that an international regime on outer space resources must include '[a]n equitable sharing by all States Parties in the benefits derived from those resources'). 
mandate of listing the internationally recognised heritage sites and monitoring, including reviewing, the implementation of the international framework. In my view, this would directly contribute to the realisation of the principle of free access to outer space set forth in Article I of the Outer Space Treaty. It would also comply with the provisions of Article 5, paragraph 1, of the Moon Agreement requiring States to inform the UN Secretary-General and the international community of their activities on the Moon, thus satisfying the international obligations of the signatories to the Artemis Accords who have also signed or ratified the Moon Agreement.

Finally, Building Block 19 provides a list of available dispute settlement mechanisms - adjudicatory, non-adjudicatory and hybrid ones. They are the mechanisms currently in use to facilitate the peaceful solution of disputes arising from outer space activities. The provision is uncontroversial and does not promote one particular method over the others. It simply reinforces the broader principle of peaceful uses of outer space. A provision along these lines would be a welcome addition to the text of the Artemis Accords as well.

\section{CONCLUSION}

The Artemis Accords are an international framework for cooperation in the sustainable human exploration of outer space designed to be compliant with the obligations of the Outer Space Treaty. Although not binding, they provide a principled approach for conducting space resource activities. A characteristic of the Artemis Accords is that they encourage and facilitate the implementation of the Outer Space Treaty's obligations even in the absence of an international instrument regulating the exploitation of outer space resources. Specifically, by replacing the concept of anticipatory regulation with the principle of adaptive governance as the basis of international cooperation in this field, the Artemis Accords present themselves as a starting point for further discussion of an international framework on space resource activities. Indeed, several provisions of the Artemis Accords call for further elaboration in a multilateral context. Given the current stage of development of space technology, the feasibility of the commercial exploitation of the natural resources of the Moon and other celestial bodies appears imminent. As a result, breaking the impasse created by the adoption of the Moon Agreement in 1979 appears both necessary and advisable. The Artemis Accords provide a concrete step in that direction.

Overall, it appears that the Artemis Accords are highly innovative. By operating within the remit of the multilateral treaties on outer space, they advance the development of international space law without revolutionising it. 